\title{
The Absence of Sympathoexcitation During the Development of Hypertension in Cyp1a1 Ren-2 Transgenic Rats
}

\author{
J. ZICHA ${ }^{1}$, S. HOJNÁ ${ }^{1}$, L. KOPKAN ${ }^{2}$, L. ČERVENKA ${ }^{2}$, I. VANĚČKOVÁ ${ }^{1}$ \\ ${ }^{1}$ Institute of Physiology of the Czech Academy of Sciences, Prague, Czech Republic, ${ }^{2}$ Institute of \\ Clinical and Experimental Medicine, Prague, Czech Republic
}

Received February 22, 2019

Accepted March 5, 2019

\section{Summary}

The insertion of mouse renin gene (Ren-2) into the genome of normotensive rats causes a spontaneous rise of blood pressure (BP), leading to an angiotensin II (Ang II)-dependent form of hypertension in transgenic (mRen-2)27 rats (TGR). However, enhanced sympathetic BP component was demonstrated in heterozygous TGR aged 20 weeks. In the present study we used another model, i.e. Cyp1a1-Ren-2 transgenic rats (iTGR) in which hypertension can be induced by natural xenobiotic indole-3 carbinol (I3C) added to the diet. We investigated whether the development of high blood pressure (BP) in 5-month-old iTGR animals fed I3C diet for 10 days is solely due to enhanced Ang II-dependent vasoconstriction or whether enhanced sympathetic vasoconstriction also participates in BP maintenance in this form of hypertension. Using acute sequential blockade of renin-angiotensin system (RAS), sympathetic nervous system (SNS) and NO synthase (NOS) we have demonstrated that the observed gradual increase of BP in iTGR fed I3C diet was entirely due to the augmentation of Ang II-dependent BP component without significant changes of sympathetic BP component. Thus, the hypertension in iTGR resembles to that of homozygous TGR in which high BP was entirely dependent on Ang II-dependent vasoconstriction. Moreover, our measurements of acute BP response to Rho kinase inhibitor fasudil in animals subjected to a combined blockade of RAS, SNS and NOS indicated the attenuation of basal calcium sensitization in both iTGR and homozygous TGR.

\section{Key words}

Indole-3 carbinol • Blood pressure $\bullet$ Angiotensin II • Sympathetic nervous system $\bullet$ Nitric oxide $\bullet$ Rho kinase pathway $\bullet$ Fasudil

\section{Corresponding author}

J. Zicha, Institute of Physiology CAS, Vídeňská 1083, 14220 Prague 4, Czech Republic. E-mail: zicha@biomed.cas.cz

Chronic infusion of angiotensin II (Ang II) causes hypertension in rats (Brown et al. 1981, Fink et al. 1987). Although Ang II-dependent vasoconstriction plays an important role in this form of experimental hypertension, enhanced sympathoexcitation also participates in later stages of Ang II-induced hypertension (Kline et al. 1990).

The insertion of mouse renin gene (Ren-2) into rat genome produced two interesting models of Ang II-dependent hypertension. Transgenic (mRen-2)27 rats (TGR) with spontaneous hypertension development are based upon Sprague Dawley rats (Mullins et al. 1990), whereas Cyp1a1-Ren-2 transgenic rats (iTGR) with inducible hypertension are based upon Fischer 344 rats (Kantachuvesiri et al. 2001). High blood pressure (BP) develops spontaneously in TGR, whereas hypertension is elicited in iTGR by feeding a diet containing natural xenobiotic indole-3 carbinol (I3C).

Our previous studies in TGR indicated that the enhanced Ang II-dependent BP component can be found not only in homozygous animals but also in heterozygous TGR during the earlier stages of hypertension development, i.e. in animals younger than 10 weeks of age (Vaněčková et al. 2012). The importance of sympathetic vasoconstriction in BP maintenance is increasing with age in heterozygous TGR and this BP component becomes dominant at 20 weeks of age (Vaněčková et al. 2012). The presumed mechanism 
responsible for this sympathoexcitation seems to be the stimulation of certain brain centers (including rostral ventrolateral medulla, RVLM) by angiotensin II (Andreatta et al. 1988). Indeed, chronic intracerebroventricular infusion of the blockers of renin-angiotensin system (losartan or aliskiren) lowered BP of adult heterozygous TGR aged 4 months by the reduction of sympathetic BP component (Zicha et al. 2018).

Vascular smooth muscle contraction is dependent on both calcium influx (through L type voltage-gated $\mathrm{Ca}^{2+}$ channels) and calcium sensitization (mediated by Rho kinase pathway) (for review see Zicha et al. 2014a). Endogenous Ang II seems to augment calcium sensitization because chronic captopril treatment attenuated BP reduction elicited by the acute administration of Rho kinase inhibitor fasudil (Brunová et al. 2015). Our recent study demonstrated augmented BP response to fasudil in homozygous TGR (Vaněčková et al. 2019).

On the other hand, there is no information on the possible participation of sympathetic vasoconstriction in the other model, i.e. inducible Cyplal transgenic rats. Therefore, we studied the participation of reninangiotensin system (RAS) and sympathetic nervous system (SNS) in BP maintenance of iTGR subjected to feeding I3C diet for 3 or 10 days. We also tried to evaluate Rho kinase-dependent calcium sensitization in normotensive and hypertensive iTGR.

Adult male Cyp1a1 Ren-2 transgenic rats aged 5 months were housed at $23{ }^{\circ} \mathrm{C}$ under a $12 \mathrm{~h} \mathrm{light/dark}$ cycle, given natural ingredient diet $(0.4 \% \mathrm{NaCl}$, SEMED, Prague) and tap water ad libitum. All rats used in this study were bred at the Institute of Clinical and Experimental Medicine from stock animals kindly supplied by Prof. John J. Mullins (Center for Cardiovascular Science, University of Edinburgh, UK). Hypertension was induced by feeding a diet containing xenobiotic indole-3 carbinol $(0.3 \%)$ for 10 days. The animals were studied either in the early stage of hypertension development (3 days of I3C diet feeding) or at the end of the experiment, i.e. after 10 days of I3C diet feeding.

The participation of major vasoactive systems in BP maintenance (vasoactive balance) was studied using the changes of mean arterial pressure (MAP) elicited by the sequential blockade of major vasoconstrictor and vasodilator systems (RAS, SNS and NO) in conscious rats. One day prior to the determination of vasoactive balance, two polyethylene cannulas were implanted in $2.5 \%$ isoflurane anesthesia (PE 50 for BP measurement in the left carotid artery, PE 10 for the infusion of drugs to the jugular vein) and were exteriorized in the interscapular region. In the evening before the experiment, I3C (100 mg/kg) was given by gastric gavage to prevent decreased I3C intake after the surgery. Next morning, blood pressure and heart rate were recorded using a pressure transducer and a multichannel recorder (ADInstruments, Bella Vista, Australia). We used a modified protocol of Minami et al. (1995) as modified in our lab (Kuneš et al. 2002). Briefly, baseline MAP levels were recorded after a 30-min adaptation period in transparent measuring plastic cages. Then, we started with RAS blockade (captopril $10 \mathrm{mg} / \mathrm{kg}$ ) which was followed $15 \mathrm{~min}$ later by ganglionic blockade of SNS (pentolinium $5 \mathrm{mg} / \mathrm{kg}$ ). Thereafter, NO synthase (NOS) inhibitor (30 mg/kg L-NAME) was added and BP was monitored for further $20 \mathrm{~min}$. Finally, the inhibition of Rho kinase pathway was induced by increasing doses of fasudil (1, 2, 4 and $4 \mathrm{mg} / \mathrm{kg}$ ). All drugs (except fasudil) were purchased from Sigma (St. Louis, Missouri, USA), dissolved in saline and administered as intravenous bolus injections in a volume of $1 \mathrm{ml} / \mathrm{kg}$ of body weight. Fasudil (HA-1077) was purchased from LC Laboratories, Woburn, MA, USA).

The results are expressed as the mean \pm SEM. The statistical differences were evaluated by one-way ANOVA (Instat, La Jolla, California, USA) followed by the Fisher least significant difference (LSD) post-hoc test. $\mathrm{P}<0.05$ values were considered to be statistically significant.

All procedures and experimental protocols were approved by the Ethical Committee of the Institute of Physiology, Czech Academy of Sciences (Protocol Nr. 139/2013), and they conform to the European Convention on Animal Protection and Guidelines on Research Animal Use (Directive 2010/63/EU).

A short-term feeding of iTGR animals with I3C diet for 3 days did not cause a significant BP increase, although there was a borderline augmentation of the Ang II-dependent BP component (Fig. 1A). On the contrary, a significant BP elevation was observed in iTGR after feeding this diet for 10 days. At this stage of hypertension development the Ang II-dependent BP component was threefold increased (Fig. 1B). It should be noted that sympathetic BP component was not significantly changed during the entire experiment (Fig. 1C). There was a stepwise reduction of NO-dependent BP component which became significant in iTGR fed I3C for 10 days (Fig. 1D). 
A

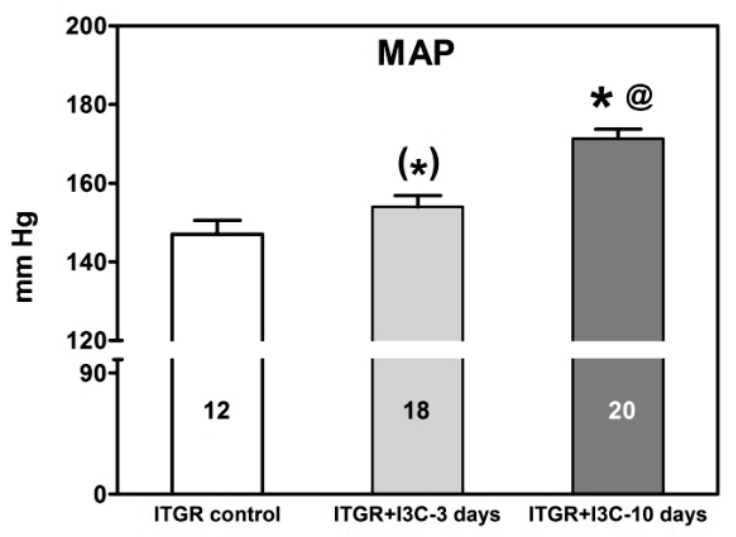

C

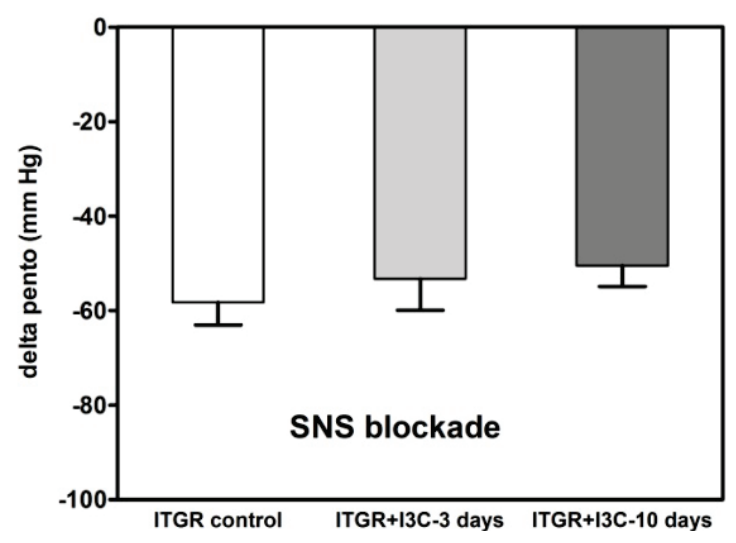

B

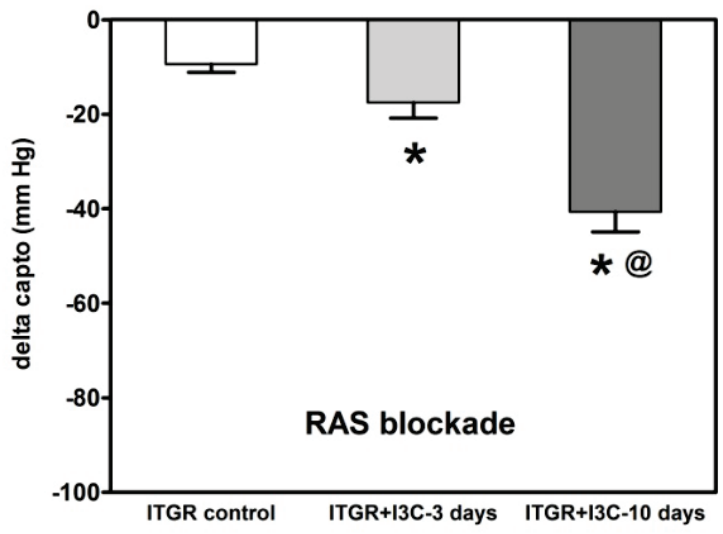

D

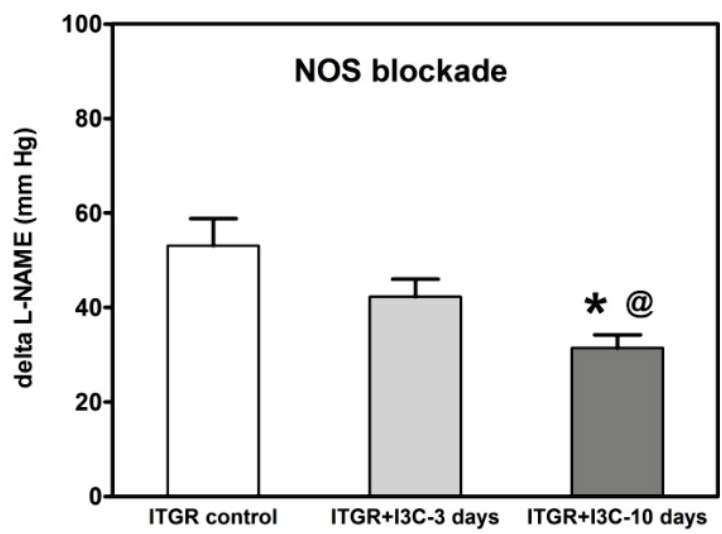

Fig. 1. The participation of renin-angiotensin system (RAS), sympathetic nervous system (SNS) and nitric oxide (NO) in BP maintenance in Cyp1a1 Ren-2 transgenic rats (iTGR) fed a diet containing indole-3 carbinol (0.3\% I3C) for 3 or 10 days. Basal MAP level in conscious rats (A) as well as MAP changes elicited by the acute RAS blockade with captopril (capto, B), SNS blockade with pentolinium (pento, C) and blockade of NO synthase with L-NAME (D) were recorded in conscious cannulated rats. Significant differences: $* p<0.05$ vs. controls, $\left({ }^{*}\right) p<0.10$ vs. controls, @ $p<0.05$ vs. iTGR fed I3C diet for 3 days. Data are mean \pm SEM. Number of animals is shown in the respective columns.

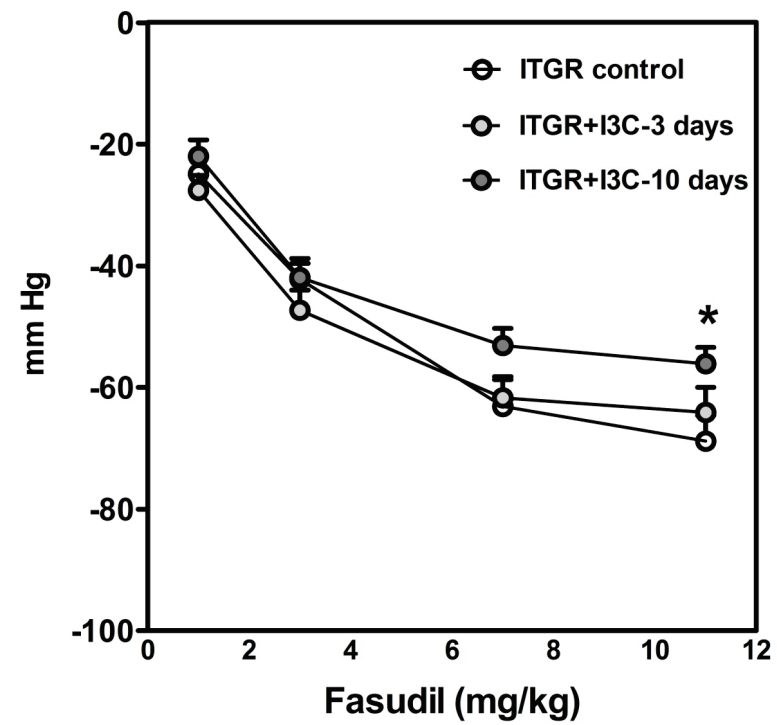

Fig. 2. The changes of mean arterial pressure (MAP) elicited by intravenous injection of increasing cumulative doses of fasudil to iTGR animals which were subjected to the sequential blockade of RAS, SNS, NOS prior to fasudil administration. Significant difference: $* \mathrm{p}<0.05$ vs. controls. Data are mean \pm SEM.
BP response to the dose-dependent inhibition of Rho kinase pathway by fasudil was similar in iTGR controls and iTGR fed I3C diet for three days, but we observed the attenuation of this response in iTGR fed I3C diet for 10 days (Fig. 2). This attenuation was significant only at the highest dose of fasudil. When we analyzed the relationship between particular BP components and basal BP, we observed a highly significant correlation of captopril-induced MAP changes with basal MAP (Fig. 3A) but there was no significant correlation of basal MAP with either pentoliniuminduced MAP changes (Fig. 3B) or with MAP changes elicited by NOS blockade with L-NAME (Fig. 3C). On the other hand, the correlation of L-NAME-induced MAP changes with those elicited by the highest fasudil dose was highly significant (Fig. 3D).

Our study confirmed that hypertension induced by the increased Ren- 2 expression in iTGR fed a diet with $0.3 \%$ indole- 3 carbinol is fully dependent on the 
increased Ang II-dependent vasoconstriction (Vaňourková et al. 2006, Williams et al. 2010). On the contrary, no augmentation of sympathetic BP component was observed during 10 days of $\mathrm{I} 3 \mathrm{C}$ diet feeding. Thus, we failed to prove the hypothesis that high levels of circulating Ang II would penetrate into the brain to cause sympathoexcitation, although increased sympathetic tone seems to be the major mechanism of high BP in other hypertensive models (Zicha et al. 2001, Kuneš et al. 2002, Pecháňová et al. 2004, Zicha et al. 2014b). It is true that we did not observe the increased sympathetic
BP component in TGR before the age of 20 weeks (Vaněčková et al. 2012). Nevertheless, the onset of hypertension in TGR is not as fast as that in iTGR fed I3C diet. Howard et al. (2005), Vaňourková et al. (2006) or Husková et al. (2010), who utilized tail-cuff method or radiotelemetry for BP measurement, reported highly significant BP elevation already during the first two days of $\mathrm{I3C}$ diet feeding. However, in our study there was a considerably slower BP rise, reaching hypertensive values after 10 days of I3C diet feeding.

\section{Basal MAP vs. delta pento}

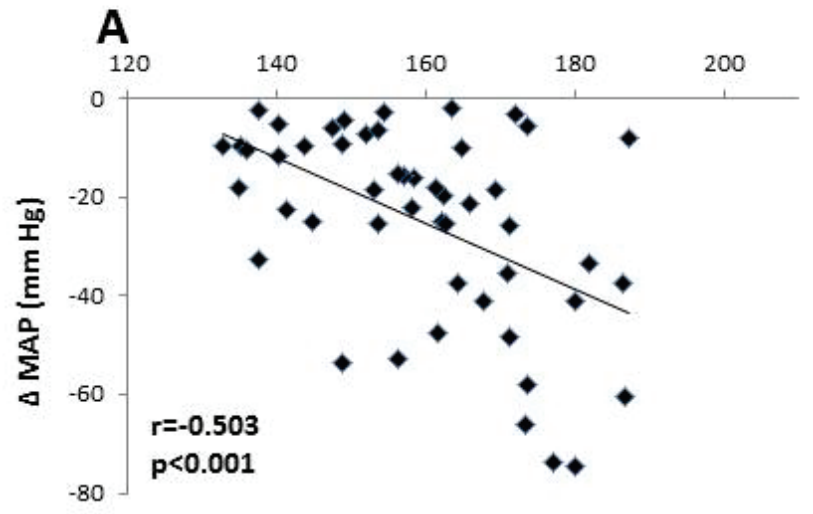

Basal MAP vs. delta L-NAME

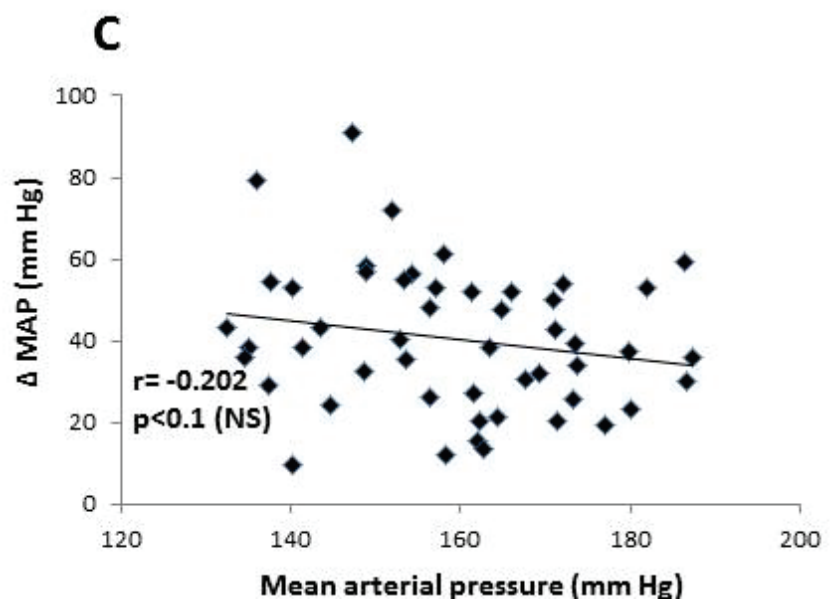

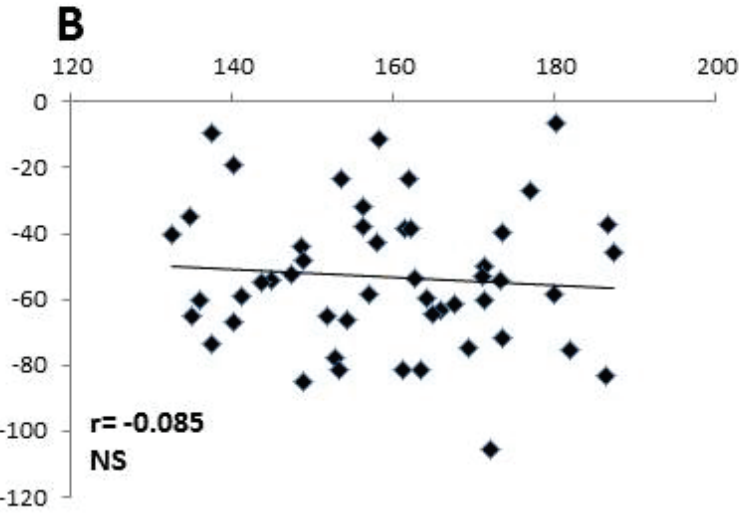

Delta L-NAME vs. delta fasu

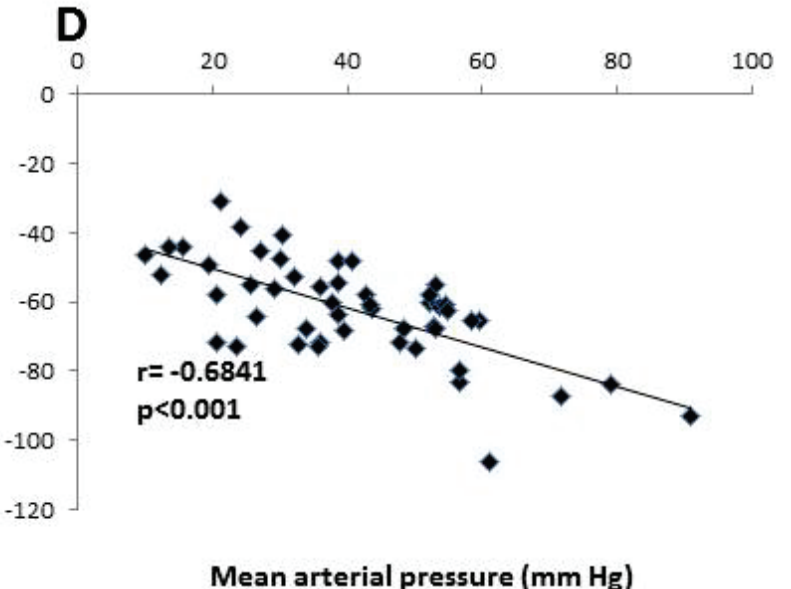

Fig. 3. The correlations of basal MAP with MAP response to acute RAS blockade by captopril (capto, A), MAP response to acute SNS blockade by pentolinium (pento, B) and acute NOS blockade by L-NAME (C) as well as the correlation of MAP changes elicited by acute NOS blockade by L-NAME with those induced by the highest fasudil dose (fasu, D).

As far as calcium sensitization of iTGR is concerned, we have studied BP response to fasudil in animals subjected to a complete blockade of RAS, SNS and NOS. Under such conditions fasudil elicited greater BP reduction in normotensive Hannover Sprague Dawley controls than in hypertensive TGR. These findings indicate attenuated calcium sensitization not only in TGR (Behuliak et al. 2017, Vaněčková et al. 2019) but also in iTGR (this study).

It remains to be determined whether i) the circulating Ang II levels in iTGR were not high enough to stimulate brain centers, ii) the exposure of brain 
centers to penetrating Ang II was not long enough, or iii) Fischer 344 rats are less sensitive to central Ang II effects than Sprague Dawley animals. The alternative experiments could evaluate a possibility to counteract hypertension development in iTGR by brain RAS blockade, e.g. by intracerebroventricular infusion of $\mathrm{AT}_{1}$ receptor blocker losartan.

\section{Conflict of Interest}

There is no conflict of interest.

\section{Acknowledgements}

Technical assistance of Zdeňka Kopecká is highly appreciated. This study was supported by the Ministry of Health of the Czech Republic (grant Nr. 15-25396A).

\section{References}

ANDREATTA SH, AVERILL DB, SANTOS RA, FERRARIO CM: The ventrolateral medulla. A new site of action of the renin-angiotensin system. Hypertension 11 (Suppl I): I163-I166, 1988.

BEHULIAK M, BENCZE M, VANĚČKOVÁ I, KUNEŠ J, ZICHA J: Basal and activated calcium sensitization mediated by RhoA/Rho kinase pathway in rats with genetic and salt hypertension. Biomed Res Int 2017: 8029728, 2017.

BROWN AJ, CASALS-STENZEL J, GOFFORD S, LEVER AF, MORTON JJ: Comparison of fast and slow pressor effects of angiotensin II in the conscious rat. Am J Physiol 241: H381-H388, 1981.

BRUNOVÁ A, BENCZE M, BEHULIAK M, ZICHA J: Acute and chronic role of nitric oxide, renin-angiotensin system and sympathetic nervous system in the modulation of calcium sensitization in Wistar rats. Physiol Res 64: 447-457, 2015.

FINK GD, BRUNER CA, MANGIAPANE ML: Area postrema is critical for angiotensin-induced hypertension in rats. Hypertension 9: 355-361, 1987.

HOWARD LL, PATTERSON ME, MULLINS JJ, MITCHELL KD: Salt-sensitive hypertension develops after transient induction of ANG II-dependent hypertension in Cyp1a1-Ren2 transgenic rats. Am J Physiol Renal Physiol 288: F810-F815, 2005.

HUSKOVÁ Z, VAŇOURKOVÁ Z, ERBANOVÁ M, THUMOVÁ M, OPOČENSKÝ M, MULLINS JJ, KRAMER HJ, BURGELOVÁ M, ČERVENKA L: Inappropriately high circulating and intrarenal angiotensin II levels during dietary salt loading exacerbate hypertension in Cyp1a1-Ren-2 transgenic rats. J Hypertens 28: 495-509, 2010.

KANTACHUVESIRI S, FLEMING S, PETERS J, PETERS B, BROOKER G, LAMMIE AG, MCGRATH I, KOTELEVTSEV Y, MULLINS JJ: Controlled hypertension, a transgenic toggle switch reveals differential mechanisms underlying vascular disease. J Biol Chem 276: 36727-36733, 2001.

KLINE RL, CHOW KY, MERCER PF: Does enhanced sympathetic tone contribute to angiotensin II hypertension in rats? Eur J Pharmacol 184: 109-118, 1990.

KUNEŠ J, DOBEŠOVÁ Z, ZICHA J: Altered balance of main vasopressor and vasodepressor systems in rats with genetic hypertension and hypertriglyceridaemia. Clin Sci (Lond) 102: 269-277, 2002.

MINAMI N, IMAI Y, HASHIMOTO J, ABE K: Contribution of vascular nitric oxide to basal blood pressure in conscious spontaneously hypertensive rats and normotensive Wistar Kyoto rats. Clin Sci (Lond) 89: 177-182, 1995.

MULLINS JJ, PETERS J, GANTEN D: Fulminant hypertension in transgenic rats harbouring the mouse Ren-2 gene. Nature 344: 541-544, 1990.

PECHÁŇOVÁ O, DOBEŠOVÁ Z, ČEJKA J, KUNEŠ J, ZICHA J: Vasoactive systems in L-NAME hypertension: the role of inducible NO synthase. J Hypertens 22: 167-173, 2004.

VANĚČKOVÁ I, DOBEŠOVÁ Z, KUNEŠ J, ZICHA J: The effects of repeated delivery of angiotensin II AT receptor $_{1}$ antisense on distinct vasoactive systems in Ren-2 transgenic rats: young vs. adult animals. Hypertens Res $\mathbf{3 5}$ : 761-768, 2012.

VANĚČKOVÁ I, BEHULIAK M, HOJNÁ S, KOPKAN L, KADLECOVÁ M, ZICHA J: Exaggerated blood pressure response to fasudil or nifedipine in hypertensive Ren-2 transgenic rats: role of altered baroreflex. Hypertens Res 42: 145-154, 2019. 
VAŇOURKOVÁ Z, KRAMER HJ, HUSKOVÁ Z, VANĚČKOVÁ I, OPOČENSKÝ M, ČERTÍKOVÁ CHÁBOVÁ V, TESǍ̌ V, ŠKAROUPKOVÁ P, THUMOVÁ M, DOHNALOVÁ M, MULLINS JJ, ČERVENKA L: $\mathrm{AT}_{1}$ receptor blockade is superior to conventional triple therapy in protecting against end-organ damage in Cyp1a1-Ren-2 transgenic rats with inducible hypertension. J Hypertens 24: 2465-2472, 2006.

WILLIAMS DE, PRIETO MC, MULLINS JJ, NAVAR LG, MITCHELL KD: AT 1 receptor blockade prevents the increase in blood pressure and the augmentation of intrarenal ANG II levels in hypertensive Cyp1a1-Ren2 transgenic rats fed with a high-salt diet. Am J Med Sci 339: 356-361, 2010.

ZICHA J, DOBEŠOVÁ Z, KUNEŠ J: Relative deficiency of nitric oxide-dependent vasodilation in salt hypertensive Dahl rats: the possible role of superoxide anions. J Hypertens 19: 247-254, 2001.

ZICHA J, BEHULIAK M, PINTÉROVÁ M, BENCZE M, KUNEŠ J, VANĚČKOVÁ I: The interaction of calcium entry and calcium sensitization in the control of vascular tone and blood pressure of normotensive and hypertensive rats. Physiol Res 63 (Suppl 1): S19-S27, 2014a.

ZICHA J, DOBEŠOVÁ Z, BEHULIAK M, PINTÉROVÁ M, KUNEŠ J, VANĚČKOVÁ I: Nifedipine-sensitive blood pressure component in hypertensive models characterized by high activity of either sympathetic nervous system or renin-angiotensin system. Physiol Res 63: 13-26, $2014 \mathrm{~b}$.

ZICHA J, ŘEZÁČOVÁ L, HOJNÁ S, VANĚČKOVÁ I: Blood pressure effects of systemic or central angiotensin II in hypertensive Ren-2 transgenic rats: sympathoinhibition induced by central RAS blockade. J Hypertens $\mathbf{3 6}$ (Suppl 3): E42, 2018. 